Skąd Autorka wie, że dziecku nadawano po urodzeniu imię „domowe”, a na chrzcie inne? (s. 498) Byłby to ciekawy szczegół. Tak jak i to, na ile rzeczywiście powszechna była praktyka powtórnego ożenku. Autorka widzi tego ślady wszędzie, gdzie różnica wieku między ojcem a dzieckiem wydaje jej się za duża (s. 507). Na pewno miały one miejsce w Rzymie, ale akurat z różnicy wieku to nie wynika, gdyż Rzymianie żenili się z zasady późno. Na drugie małżeństwo wdowców (nie rozwodników) w Kościele pozwalano, ale na zasadzie wręcz pokutnej, i tacy ludzie byli traktowani jakby chrześcijanie drugiej kategorii. Podobnie wyrażenie audiens in Christo bynajmniej nie oznacza, że ktoś jest „wykształcony w wierze i ochrzczony" ale że jest zaliczony do grona katechumenów (s. 510).

Co Autorka może mieć na myśli pisząc, że „pomimo dysput teologicznych, chrześcijanie z Rzymu byli przekonani... że ich dzieci ... trafią do raju” (s. 514). Otóż nie było żadnych dysput teologicznych, w których poddawano by w wątpliwość zbawienie nowo ochrzczonych: wszyscy chrześcijanie wierzyli święcie, że chrzest gładzi grzechy i zapewnia zbawienie. Dorosły mógł to stracić czyniąc zło, dziecko jednak nie mogło, gdyż uważano, że nie jest w stanie popełnić świadomie grzechu. Ostrożnie - na szczęście - podaje Autorka hipotezę, że istniały w starożytnym chrześcijańskim Rzymie jakby sierocińce, w których wychowywano członków kleru (s. 524). Zaznacza też, że nie potwierdzają tego źródła. Oczywiście, nie potwierdzają i jest to hipoteza niczym nie poparta.

Tak więc do ogromnej masy informacji doszło trochę błędów, spowodowanych przede wszystkich prawdopodobnie pragnieniem wyjaśnienia wszystkiego i uogólnienia. Praca w całości jest jednak poważna i godna zauważenia.

Henryk Pietras SJ - Kraków, WSFP „Ignatianum”

\title{
Ks. Piotr SZCZUR, Problematyka spoleczna w późnoantycznej Antiochii na podstawie nauczania homiletycznego Jana Chryzostoma, Lublin 2008, Wydawnictwo KUL, ss. 634.
}

Badanie spuścizny literackiej Ojców Kościoła jest na pierwszym miejscu zagłębianiem się w świadectwa wiary, które do dzisiaj posiadają walor normatywny jako przekaz Tradycji. Stąd też przede wszystkim przedmiot analiz stanowią kwestie doktrynalne, które mają zasadnicze znacznie dla właściwej interpretacji „Credo” . Niemniejszą jednak wartość posiadają także wskazania moralne, zawarte w dziełach Ojców Kościoła, które - chociaż były formułowane w odmiennych uwarunkowaniach historycznych i kulturowych - to przecież zachowały świeżość i aktualność ze względu na problemy, które niezależnie od epoki pojawiają się nieustannie w życiu jednostek i społeczeństw. Szczególne miejsce w pionie etyki patrystycznej zajmuje nauka społeczna, która u Ojców Kościoła cieszyła się dużym zainteresowaniem. Wśród Ojców greckich jej czołowymi reprezentantami są: Klemens Aleksandryjski, Bazyli Wielki, Jan Chryzostom, a wśród Ojców łaciń- 
skich -Ambroży. Na rozwiązaniach, które w tamtym czasie zaproponowali właśnie ci pisarze starochrześcijańscy, bazuje współczesna katolicka nauka społeczna.

Doktryna społeczna, zawarta w przekazach patrystycznych, może być analizowana w dwojakim aspekcie: jako nauka moralna, zawierająca ponadczasowe formy postępowania, chociaż sformułowane w oparciu o konkretne sytuacje w życiu społecznym oraz jako źródło poznania historii społecznej antyku chrześcijańskiego. W pierwszym wypadku Ojcowie Kościoła występują jako nauczyciele moralności, w drugim zaś uzyskują status świadków historii. Oczywiście, obydwa wyżej wymienione aspekty warunkują metodę badań. Pierwszy aspekt domaga się na pierwszym miejscu zastosowania metody właściwej naukom teologicznym, drugi natomiast - metody właściwej naukom historycznym. Wydaje się, że wśród opracowań na ten temat, w sposób ciągle jeszcze niedostateczny, Ojcowie ukazani są jako świadkowie historii swoich czasów. Przeważa raczej wymiar doktrynalny, w którym Ojców Kościoła postrzega się jako wyrazicieli i teoretyków myśli społecznej.

$\mathrm{Z}$ tym większym więc zadowoleniem należy przyjąć monografię ks. Piotra Szczura pt. Problematyka społeczna w późnoantycznej Antiochii na podstawie nauczania homiletycznego Jana Chryzostoma, która wychodzi naprzeciw wzrastającemu zainteresowaniu przekazami Ojców jako źródłami poznania historii. Autor przedstawia cenne studium, z którego czytelnik uzyskuje ciekawy, a równocześnie złożony obraz stosunków społecznych, panujących pod koniec IV wieku w Antiochii. Bazę źródłową stanowią homilie Jana Chryzostoma głoszone w czasie jego pobytu w Antiochii, którym Autor monografii nadaje rangę dokumentu historycznego. Reprezentuje pogląd, że wartość historyczna przekazów Jana Chryzostoma nie jest umniejszona przez zastosowanie toposu literackiego, a podawane przez niego informacje zasługują na zaufanie, gdyż są raportem naocznego świadka, który w sposób niezależny opisywał zaobserwowane zjawiska.

Ks. P. Szczur przedstawia bogato dokumentowane materiałami źródłowymi studium na temat stosunków społecznych panujących w Antiochii końca IV wieku. Wartość badawcza monografii wynika także z podjętego przez Autora przedmiotu badań: Antiochia w IV w. przeżywała złoty okres swojego rozwoju. Posiadała ogromne znaczenie zarówno administracyjne jak i kulturowe. Była miastem zamieszkiwanym przez ludność zróżnicowaną nie tylko pod względem przekroju społecznego, ale także języka i religii. W chrześcijaństwie od początków jego istnienia zajmowała wyjątkową, uprzywilejowaną pozycję z racji działalności tam apostołów, zwłaszcza Piotra i Pawła. Materiał źródłowy stanowią homilie Jana Chryzostoma, głoszone właśnie w Antiochii, począwszy od 386 aż do 397 r., kiedy to Jan obejmuje biskupstwo w Konstantynopolu. Jego homilie uznawane są nie tylko za arcydzieła sztuki homiletycznej, ale także - ze względu na tematykę - za kopalnię wiedzy nt. problemów społecznych i religijnych obecnych w życiu tego miasta. Problemy te stanowią przedmiot omawianej monografii.

Została ona podzielona na siedem rozdziałów oraz „Wstęp” i „Zakończenie” . We „Wstępie” (s. 7-34) ks. P. Szczur uzasadnia, dlaczego homilie Jana Chryzostoma 
stanowią źródło historyczne służące do poznania stosunków społecznych później starożytności. Przedstawia w nim stan badań zarówno na ten temat, jak i na temat teologii Chryzostoma. Metodę zastosowaną w swoim opracowaniu określa jako historyczno-porównawczą.

Rozdział pierwszy (s. 35-123) zatytułowany „Antiochia i Kościół antiocheński - tło historyczne i środowiskowe" ma charakter wprowadzający w całość problematyki. Autor opisuje najpierw samo miasto i jego rolę zarówno w regionie jak i całym Imperium Rzymskim, a następnie przechodzi do charakterystyki jego mieszkańców i ich składu narodowościowo-religijnego. Z kolei omówione jest życie kościelno-liturgiczne w Antiochii. Na tym tle ks. Szczur próbuje ukazać osobowość i nauczanie Jana Chryzostoma, jego uzdolnienia kaznodziejskie, a także profil jego słuchaczy. Stara się zaklasyfikować ich do odpowiednich grup społecznych. Trzeba jednak zauważyć, że w tym temacie wykazuje pewne niezdecydowanie. I tak np. raz stwierdza, że rzemieślnicy byli zamożnymi członkami klasy średniej (s. 110), a nieco dalej poddaje to w wątpliwość, uważając, że byli stosunkowo biedni (s. 112).

Przedmiotem rozdziału drugiego pt. „Bogactwo” (s. 125-217), jest zagadnienie bogactwa, które Jan Chryzostom postrzega jako istotny problem swoich czasów. Na pierwszym miejscu przedstawione zostają poglądy Ojca Kościoła na temat pieniędzy. Ks. P. Szczur zauważa, że Jan Chryzostom jest zdecydowanym przeciwnikiem posiadania bogactwa. Głosi bowiem, że na ogół jest ono zdobywane na drodze oszustw, kradzieży, spekulacji, czy zawłaszczania cudzej własności. Dlatego piętnuje zarówno zbytek jak i chciwość, którą sprowadza do kategorii zniewolenia i choroby. Piętnuje przy tej okazji źle zorganizowany system fiskalny, który dotyka najboleśniej ludzi ubogich. Autor poddaje krytycznej ocenie pewne szczegółowe dane, które przy tej okazji przytacza Ojciec Kościoła. Zauważa, że antiocheński Kaznodzieja posługuje się retoryką i dlatego - mimo, że homilie mają walor dokumentu historycznego - to jednak niektóre informacje, jak ta, że pewni bogacze posiadają dziesiątki tysięcy talentów złota, należy uznać za przesadę retoryczną (s. 127). Dotyczy to również informacji o wysokości podatków (s. 212 n). Ks. Szczur dokonuje jej weryfikacji w oparciu o inne źródła, co niewątpliwie czyni pracę jeszcze bardziej interesującą.

Chociaż poglądy Jana Chryzostoma na temat bogactwa zostały przez Autora przedstawione obszernie i szczegółowo, to jednak pewien niedosyt budzi brak wskazania źródeł jego doktryny. Czytelnik oczekiwałby jasnego określenia, na ile poglądy społeczne Kaznodziei z Antiochii są oryginalne, a na ile stanowią kontynuację (a może zapożyczenie?) myśli Ojców wcześniejszych. W sposób szczególny tę zależność należałoby dostrzec w odniesieniu do Bazylego Wielkiego. Obaj byli kaznodziejami. Jan Chryzostom krytykuje nie tyle ludzi bogatych, ile raczej używanie bogactwa, odróżniając Boga - właściciela od człowieka, który jest tylko administratorem dóbr materialnych (por. s. 132). Podobnie czynił to Bazyli Wielki. Uderzająca jest zbieżność terminologii na określenie posiadania i administrowania. Identyczne są też poglądy obu Ojców Kościoła na temat war- 
tości testamentów (o czym Autor pisze w III rozdziale monografii - por. s. 254). Dokonanie tego rodzaju porównania poglądów w/w Ojców Kościoła z pewnością ubogaciłoby pracę i pogłębiło jej walor badawczy.

W trzecim rozdziale pt. „Ubóstwo” (s. 219-291) przedstawione zostaje nauczanie Jana Chryzostoma na temat ubóstwa. Ks. P. Szczur zwraca uwagę na to, że mimo trudnej sytuacji materialnej wielu ludzi, Ojciec Kościoła głosi pochwałę ubóstwa i zachęca wiernych do jego praktykowania. Nie omieszkuje przy tym jednak zaznaczyć, że obraz człowieka ubogiego nakreślony przez Chryzostoma, należy uznać za zbyt wyidealizowany. Z kolei omówione zostają rożne przejawy dobroczynności praktykowanej w Kościele antiocheńskim. Autor nie ustrzegł się w tej prezentacji pewnych powtórzeń z poprzedniego rozdziału, pisząc np., że wspieranie ubogich jest rodzajem ,inwestycji” (por. s. 214 i s. 263, a także s. 86).

Ostatnia część rozdziału trzeciego dotyczy niezwykle oryginalnej doktryny Jana Chryzostoma na temat obecności Chrystusa w ubogich i cierpiących na zasadzie analogii do obecności w Eucharystii (s. 239-269). Niestety, Autor potraktował ją zbyt skrótowo. Wydobył wprawdzie z nauczania Ojca Kościoła myśl, że „dobroczyńca stojący przed ubogim jest kapłanem stojącym przed ołtarzem” (s. 270), nie rozwinął jej jednak, ani też szerzej nie skomentował. Tymczasem jest to jedna $\mathrm{z}$ fundamentalnych idei w nauczaniu Jana Chryzostoma w ogóle, ponieważ utożsamia posługę wobec cierpiących i ubogich z posługą kapłańską i czyni równorzędną z posługą kapłana przy ołtarzu w czasie sprawowania Eucharystii. Myśl ta znalazła szczególne miejsce w teologii protestanckiej, dając podstawę do poszerzonego pojęcia kapłaństwa. Najbardziej znaczące dla tego ujęcia są opracowania R. Brändle, który jednak w tym miejscu rozprawy w przypisach nie został uwzględniony (chociaż cytowany jest w innych miejscach).

W czwartym rozdziale pt. „Małżeństwo i rodzina” (s. 293-359) podjęta zostaje tematyka małżeństwa i rodziny. Stanowi ona samodzielny i charakterystyczny dział w nauczaniu Jana Chryzostoma. Autor przypomina najpierw zasadnicze tezy jego doktryny na ten temat: świętość i nierozerwalność małżeństwa, kryteria wyboru męża lub żony, a także ich wzajemne relacje między sobą i względem dzieci. W dalszym ciągu przedstawione zostają zagrożenia dla małżeństwa i rodziny takie jak: antykoncepcja, aborcja, prostytucja, a także homoseksualizm. W tej ostatniej kwestii ks. Szczur wyakcentowuje, że według Jana Chryzostoma homoseksualizm jest chorobą, a równocześnie grzechem, ze względu na „nienaturalne uczucie" (s. 346). Autor jednak ograniczył swoją analizę do wskazania, że - zdaniem Antiocheńczyka - homoseksualizm jest grzechem szczególnie ciężkim, gdyż burzy porządek natury, a jego sprawcą jest diabeł (s. 348). Szkoda, że nie wydobył z nauczania Jana Chryzostoma jeszcze jednej ciekawej argumentacji: homoseksualizm jest, według nauczania Ojca Kościoła, także rodzajem bałwochwalstwa i wykroczeniem przeciwko oddawaniu czci należnej Bogu, czyli w konsekwencji grzechem w większym stopniu przeciwko I przykazaniu Dekalogu niż VI. Argumentacja ta jest godna uwagi w kontekście toczących się dzisiaj dyskusji na temat homoseksualizmu. Rozdział kończy się prezentacją wy- 
powiedzi Złotoustego Kaznodziei na temat dziewic i wdów oraz ich roli w życiu lokalnego społeczeństwa.

Przedmiotem piątego rozdziału pt. „Praca” (s. 361-409) jest problematyka ludzkiej pracy. Zdaniem ks. Szczura, Jan Chryzostom umieszcza ją w kontekście doktryny o bogactwie i ubóstwie oraz opiera na Piśmie Świętym. Przywołuje niektóre postacie biblijne widząc w nich wzór ludzi pracy. Autor przypomina, że w środowisku antiocheńskim szczególnie niedoceniona była praca fizyczna. Dlatego też Ojciec Kościoła akcentuje jej wartość, podnosząc pracę na roli do najbardziej godziwego sposobu zarabiania na swoje utrzymanie. Godne uwagi są też poglądy Jana Chryzostoma na temat niewolnictwa. Uważa je za rzecz nienaturalną, jednakże swoje apele zawęża tylko do humanitarnego traktowania niewolników; nie propaguje ich wyzwalania. Autor słusznie zauważa, że Ojciec Kościoła ogranicza się raczej do roli mediatora pomiędzy właścicielami niewolników, a niewolnikami (s. 409).

W szóstym rozdziale pt. „Rozrywka” (s. 411-563) ks. P. Szczur podejmuje kwestię stosunku Jana Chryzostoma do rozrywki. Równocześnie wydobywa z jego homilii dane dotyczące rodzaju rozrywek, jakie znała starożytna Antiochia. Na pierwszym miejscu należały do nich przedstawiania teatralne i igrzyska olimpijskie. Kaznodzieja z Antiochii uważał jednak, że są one nieodpowiednie dla chrześcijanina, także z tego powodu, że wywierają negatywny wpływ na życie rodzinne i religijne. Jan Chryzostom zarzuca przedstawieniom teatralnym rozwiązłość i dlatego postuluje zamknięcie teatrów. Homilie Antiocheńczyka dają także obraz uczt i przyjęć, jakie miały miejsce w mieście. Kaznodzieja krytykuje ich uczestników za pijaństwo i obżarstwo oraz wzywa do umiaru, jawiąc się jako surowy i wymagający asceta. Również jego stosunek do śpiewu i tańca jest negatywny. Ks. Szczur skupił się w tym rozdziale przede wszystkim na wypunktowaniu krytyk Jana Chryzostoma dotyczących rozrywek, co też zdominowało jego treść. Może byłoby lepiej, gdyby najpierw zostały przedstawione i scharakteryzowane rodzaje rozrywek, o których dowiadujemy się z homilii Kaznodziei, a dopiero w drugiej części omówiony został jego krytyczny stosunek do nich. Jest to niewątpliwie trudniejsze, ale byłoby bardziej wierne metodzie i tematowi rozprawy, w której homilie Jana Chryzostoma są traktowane jako dokument historyczny.

Ostatni siódmy rozdział pt. „Obecność innowierców w Antiochii jako problem społeczny" (s. 465-551) poświęcony został zagadnieniu obecności różnych grup wyznaniowych i religijnych w Antiochii. Moim zdaniem autor słusznie włączył je do problematyki społecznej, ponieważ wzajemne relacje między chrześcijanami, żydami, poganami i ,judaizantes" wpływały z całą pewnością na obraz społeczeństwa ówczesnej Antiochii. Jan Chryzostom wiele uwagi poświęcił obecności Żydów w mieście. Na pierwszy rzut oka jego stosunek do Żydów trzeba by ocenić jako bardzo negatywny. Ojciec Kościoła nie unika inwektywy wobec kultu żydowskiego, jak również obraźliwych epitetów wobec samych Żydów. Ks. Szczur próbuje wykazać, że nie oznacza to jednak, iż Jan Chryzostom był antysemitą. Słusznie zauważa, że adresatami jego homilii byli nie Żydzi, lecz chrze- 
ścijanie, których starał się $\mathrm{w}$ ten sposób powstrzymać od uczestnictwa w praktykach judaistycznych. Tak zwani ,judaizantes" stanowili poważny problem dla Kościoła antiocheńskiego tamtych czasów. Stąd - jak podkreśla Autor - należy rozumieć zatroskanie Kaznodziei o czystość kultu antiocheńskiego. Przy tej okazji ks. P. Szczur czyni ciekawe spostrzeżenie, potwierdzające jego tezę, że Jan Chryzostom miał wśród Żydów wielu sympatyków, co potwierdza jego list do papieża Innocentego (por. s. 485).

W podobnych kategoriach należy umieścić stosunek Jana Chryzostoma do pogan. Autor zwraca uwagę na fakt, że Ojciec Kościoła charakteryzuje Hellenów jako ludzi nie do końca złych, aczkolwiek jeszcze nie chrześcijan (por. s. 526). Poświęca im wiele uwagi, wiążąc z nimi cele misyjne. Ks. P. Szczur zauważa w tym kontekście, że stanowili oni wtedy prawie połowę mieszkańców miasta. Piętnując wierzenia i niektóre obyczaje pogańskie Jan Chryzostom ma na celu przestrzeżenie chrześcijan przed ich bezkrytycznym przyjmowaniem. Wiara w astrologię, wróżby i zabobony prowadzi nieuchronnie do idolatrii. Kierując się troską duszpasterską Kaznodzieja chce przed nią uchronić swoich wiernych poprzez rozsądną i wyważoną krytykę praktyk pogańskich. Rozdział kończy prezentacja grup heterodoksyjnych obecnych w Antiochii, o których jest mowa w homiliach Jana Chryzostoma. Należą do nich przede wszystkim gnostycy, manichejczycy, a także znaczna liczba arian i pneumatomachów. Ks. Szczur nie wchodzi w szczegóły merytoryczne poglądów głoszonych przez ich reprezentantów, lecz ogranicza się do potraktowania ich jako źródłowego przekazu historycznego.

W „Zakończeniu” (s. 553-561) ks. P. Szczur dokonuje ciekawej oceny homilii Jana Chryzostoma. Najpierw dotyczy ona próby ustalenia, na ile aktywność kaznodziejską Ojca Kościoła można uznać za reformatorską. Autor uważa, że polega ona na formowaniu zasad chrześcijańskich stosunków społecznych, a tym samym tworzeniu nowej formy poczucia wspólnoty. Na drugim miejscu zaś na budzeniu współczucia u słuchaczy dla nędzy licznych żebraków żyjących w Antiochii. Zdaniem ks. P. Szczura do poczynań reformatorskich należy zaliczyć także próbę wprowadzenia przez Jana Chryzostoma chrześcijańskiej kultury świętowania (s. 557-558). Do oceny homilii należy także odpowiedź na pytanie, jak były one przyjmowane przez słuchaczy. Ks. Piotr Szczur dochodzi do konstatacji, że słuchacze, chociaż często nie kryli aplauzu dla Złotoustego, to jednak nie chcieli postępować zgodnie z jego napomnieniami. Za ważny należy uznać wniosek: „Antiocheńczycy nie odmówili swojej akceptacji wezwaniu do życia chrześcijańskiego jako takiego, lecz raczej nie przyjęli pojęcia tożsamości chrześcijańskiej zaproponowanej przez Chryzostoma" (s. 558). Ta pesymistyczna (lecz realistyczna!) konkluzja zostaje jeszcze przez Autora wzmocniona stwierdzeniem, że sukces Jana Chryzostoma należy widzieć na płaszczyźnie retoryki, a nie w dziedzinie pragmatyki życia chrześcijańskiego (s. 561).

Monografię zamyka obszerna bibliografia (s. 563-597) oraz indeksy dzieł autorów starożytnych (s. 603-614). Wydaje się, że w tak imponującym zestawie bibliograficznym nie powinny w dziale „Opracowania” znaleźć się podręczni- 
ki np. F. Drączkowski, Patrologia, czy H. Pietras, Początki teologii Kościoła. Należałoby je przenieść do działu „Pomoce” .

Mimo przedstawionych powyżej uwag krytycznych należy podkreślić, że ks. Piotr Szczur przedstawił monografię cechującą się dojrzałością przemyśleń i kompetencją $\mathrm{w}$ naświetlaniu problemów. Czytelnik otrzymał wyczerpujący obraz stosunków społecznych w Antiochii końca IV wieku w oparciu o homilie Jana Chryzostoma. Autor przekonująco udowodnił, że homilie te nie tylko można, ale trzeba traktować także jako dokument historyczny. W ten sposób dokonał pewnego przewartościowania spuścizny literackiej Jana Chryzostoma (i chyba nie tylko jego), polegającego na zakwalifikowaniu przekazów patrystycznych do źródeł także natury historycznej, stanowiących - niezależnie od ich zawartości teologicznej - autentyczne świadectwo epoki. Dzieła Ojców Kościoła zatem stanową bezcenny warsztat badawczy nie tylko dla teologów, ale także dla historyków. Opracowanie ks. Piotra Szczura wpisuje się na pierwszym miejscu jako ważny przyczynek dla historii Kościoła starożytnego, stanowiąc kompleksowo ujęte studium nad problematyką społeczną w Antiochii w czasach Jana Chryzostoma. W ramach tej tematyki można je uznać za pionierskie. Biorąc zaś pod uwagę analizę homilii Jana Chryzostoma należy uznać je także za cenny wkład na gruncie patrystyki.

Ks. Bogdan Częsz - Poznań, UAM

\section{Piotr ŚWIERCZ, Jedność wielości. Świat, człowiek, państwo w refleksji nur- tu orficko-pitagorejskiego, Katowice 2008, Wydawnictwo Uniwersytetu Śląskiego, ss. 374.}

Opublikowana w 2008 r. książka Piotra Świercza pt. Jedność wielości. Świat, człowiek, państwo w refleksji nurtu orficko-pitagorejskiego stanowi najpoważniejszą pozycję w polskiej bibliografii na temat orfizmu. Polskie badania nad tekstami orfickimi, świadectwami na temat orfików i problematyką orficką przedstawiają się, oględnie mówiąc, bardzo skromnie. Od czasów bowiem wydania Studiów orfickich Adama Krokiewicza w 1947 r. (A. Krokiewicz, Studia orfickie, Warszawa 1947, reedycja: 2000) nie pojawiła się w Polsce żadna naukowa publikacja, ukazująca w całości i w szerszej perspektywie ten tajemniczy mistyczno-religijny nurt, obecny w greckiej filozofii i literaturze przez prawie tysiąc dwieście lat jej rozwoju (VI w. prz. Chr. - VI w. po Chr.).

W latach 80- i 90-tych XX wieku pojawiały się co prawda sporadyczne publikacje na temat anonimowych hymnów orfickich (J. Gajda - J. Dziubiński A Orzechowski, Hymny orfickie. Prawda. Prehistoria pojęcia, Studia z Filozofii Starożytnej 3, Wrocław 1993) i orfizmu w literaturze greckiej III/IV wieku po Chr. (R. Popowski, Orfizm w opisach Kallistratosa, RH 36:1988, 119-127). Pewien wzrost zainteresowania tematyką orficką w Polsce dał się zauważyć po 2000 roku, czyli w tym czasie, gdy stan badań na świecie i związaną z nim literaturę przedmiotu można byłoby śmiało określić mianem eksplozji. W 2003 roku pojawił się 